Original Article

\title{
Knowledge and Attitude Regard to Cord Blood of Early Postpartum Women after Donating Cord Blood or Storing Cord Blood
}

\author{
Kim, Mi $\mathrm{Ok}^{1)} \cdot$ Yoo, Ji Soo ${ }^{2)} \cdot$ Park, Chang $\mathrm{Gi}^{3)} \cdot$ Ahn, Hyun $\mathrm{Mi}^{1)}$ \\ 1) Graduate Student, College of Nursing, Yonsei University \\ 2) Professor, The Nursing Policy Research Institute, College of Nursing, Yonsei University \\ 3) Senior Health Economist, College of Nursing, University of Illinois at Chicago, Chicago, Illinois, USA
}

\section{제대혈 기증·보관한 산부의 제대혈 관련 지식 및 태도$$
\text { 김미옥 }{ }^{1)} \cdot \text { 유지수 }{ }^{2)} \cdot \text { 박창기 }^{3)} \cdot \text { 안현미 }{ }^{1)}
$$ \\ 1) 연세대학교 간호대학 대학원생, 2) 연세대학교 간호대학 교수 \\ 3) Senior Health Economist, College of Nursing, University of Illinois at Chicago}

\section{Abstract}

Purpose: There is increasing necessity of using cord blood cell worldwide. In order to improve the effectiveness of cord blood's usage in Korea, the study of knowledge and attitude regarding cord blood is needed. Method: As descriptive correlation study, data was collected from 212 early postpartum women who stored or donated cord blood from 2007 April to July. Data was analyzed using $\chi^{2}$-test, t-test, ANOVA, and logistic regression. Result: Total score of knowledge and attitude of early postpartum women who donated cord blood was higher than who stored. According to the source of education and the source of influence toward decision of using cord blood, early postpartum women who educated or influenced by mass media showed difference in attitude. Job status and income, and attitude of cord blood were the predictor of cord blood donation. Conclusion: Attitude regard to cord blood affect to usage of cord blood, and the attitude and knowledge of cord blood in early postpartum women who donated it higher than who stored.

Key words : Knowledge, Attitude, Cord blood

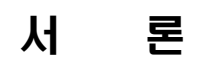

제대혈속에는 혈액세포를 생성하는 조혈모세포, 연골과 뼈, 근육, 지방 및 신경 등을 만드는 간엽줄기세포 등이 다량 포 함되어 있으므로 백혈병을 비롯한 각종 악성 혈액질환 및 암, 선천성 대사장애, 면역장애 질환 등 수십 여 난치성 질환 치 료의 가장 확실한 치료방법으로 평가 받고 있을 뿐 아니라 최근 관심이 집중되고 있다(Arcese et al., 2006). 제대혈 이식 은 1988년 프랑스에서 처음으로 실시하여 성공을 거둔 이 후 그 효용성이 지속적으로 입증되면서 현재 전 세계적으로 확 
산되고 있다(Han, 2001). 미국과 유럽 등 의료선진국에서는 제대혈 이식이 기존의 골수이식을 보완, 대체하는 새로운 의 료기술로 자리 잡고 있으며(Han, 2001), 제대혈을 이용한 가 시적 치료성과들이 속속 발표되고 있고, 이와 관련된 연구도 활발히 이루어지고 있어 머지않아 그 유용성은 더욱 확대될 전망이다(Arcese et al., 2006).

우리나라의 경우에도 제대혈 이식건수가 증가하고 있는데 (Kim, 2008), 제대혈 이식이 활성화됨에 따라 제대혈 보관의 중요성이 부각되면서 그에 따라 자연스레 제대혈 은행에 대 한 관심 또한 고조되었고, 2007년 1월 집계 결과 국내 16 개의 제대혈 은행이 설립되기에 이르렀다(YTN, 2007). 그러나 현재 기증되어 저장되거나 개인 보관되고 있는 제대혈은 전체 제 대혈의 10 분의 1 에 불과한 것으로 집계되고 있으며, 제대혈을 기증하는 경우는 제대혈을 개인 보관하는 경우에 비해 더 작 은 것으로 추정되고 있다(Kim, 2008). 그리하여 제대혈 활용 을 최대화하기 위한 노력으로 제대혈 기증을 원하는 산모로 부터 제대혈을 기증받아 저장했다가 조직적합항원이 일치하는 환자에게 제공하는 공여 제대혈 은행을 설립하고, 기증캠페인 을 벌리는 등의 노력을 하기에 이르렀고, 그 결과 지난해 말 을 기준으로 우리나라 공여 제대혈 수는 2만 6천 단위를 기 록한 바 있다(Kim, 2008).

이렇듯 제대혈 기증 혹은 개인 보관과 같은 제대혈의 활용 의 확산을 위해서는 홍보와 더불어 체계적 교육을 통한 인식 의 변화가 요구되며, 이와 함께 임부들의 제대혈 관련 지식과 태도에 대한 연구도 활발히 전개되어져야 할 필요가 있을 것 이다. 그러나 현재까지 우리나라의 제대혈 관련 연구는 제대 혈 유용성과 제대혈 활용에 대한 임부들의 인식을 조사하는 데에만 그치고 있는 실정이며, 그 또한 주로 제대혈을 가족 제대혈 은행에 개인 보관하는 임부들의 경우에만 초점을 맞 추고 있다.

이에 제대혈을 기증 혹은 개인 보관하는 등 제대혈을 활용 한 산부들을 대상으로 하여 제대혈에 관한 지식 및 태도를 파악하고 제대혈 기증 혹은 보관에 관한 관련요인을 파악함 으로, 제대혈 공여에 대한 교육의 필요성과 공여 제대혈 은행 의 효율적이고 공정한 차원의 운영시스템에 대한 사회적 신 뢰를 높이는 데에 기여할 수 있고, 나아가서는 공여 제대혈 은행의 국가적 차원의 운영시스템을 통해 제대혈 활용을 활 성화하는 기초자료로 사용하고자 본 연구를 시도하였다.

\section{1. 연구 목적}

본 연구는 제대혈 관련 지식 및 태도를 파악하고 제대혈 기증과 보관에 관한 관련요인을 규명하기 위함이며 그 구체 적인 목적은 다음과 같다.
1) 대상자의 제 특성에 따른 제대혈 기증과 보관 실태를 파악 한다.

2) 제대혈 기증과 보관 여부에 따른 제대혈 관련 지식 정도를 파악한다.

3) 제대혈 기증과 보관 여부에 따른 제대혈 관련 태도 정도를 파악한다.

4) 제대혈 관련 교육 여부와 정보출처에 따른 제대혈 관련 지 식 및 태도 정도를 파악한다.

5) 제대혈 활용의 결정에 영향을 준 출처에 따른 제대혈 관련 지식 및 태도 정도를 파악한다.

6) 제대혈 기증과 보관의 관련 요인을 파악한다.

\section{2. 용어 정의}

1) 제대혈 기증과 보관

본 연구에서 제대혈 기증이란 공여 제대혈 은행에 기증하 는 경우를 말하며, 제대혈 보관이란 산부가 분만 시 자신의 제대혈을 폐기하지 않고 가족 제대혈 은행에 개인 보관한 경 우를 말한다.

2) 제대혈 관련 지식

본 연구에서 제대혈 관련 지식이란 제대혈의 활용에 대한 일반적 지식과 제대혈 보관과 기증에 대한 지식을 의미하는 것으로, Lee(2006)가 개발한 제대혈 이식에 대한 지식에 관한 설문지를 바탕으로 하여 본 연구자가 수정 보완한 설문지를 말한다. 제대혈에 관한 일반적 지식 15 문항, 제대혈 보관에 관한 지식 5 문항, 제대혈 기증에 관한 지식 4 문항 총 24 문항 으로 구성되며 점수가 높을수록 제대혈 관련 지식이 높음을 의미한다.

3) 제대혈 관련 태도

본 연구에서 제대혈 관련 태도란 제대혈 활용에 대한 일반 적인 태도와 제대혈 기증과 보관에 대한 태도를 의미하는 것 으로, 본 연구자가 전문가 집단 17 명의 검정과 자문을 거쳐 구성한 설문지로 측정한 점수를 말한다. 이는 일반적 태도 5 문항, 보관에 관한 태도 3 문항, 기증 관련 태도 1 문항 총 9 문 항으로 구성되며, 점수가 높을수록 긍정적인 태도를 의미한다.

\section{연구 방법}

\section{1. 연구 설계}

본 연구는 산부의 제대혈 관련 지식 및 태도와 제대혈 기 증과 보관의 관련요인을 알아보기 위한 서술적 상관관계연구 
(descriptive correlational research)이다.

\section{2. 연구 대상 및 자료수집}

본 연구는 제대혈 회사 홍보처가 병원 내 산재하고 있는 서울, 경기 소재 2 곳의 산부인과 전문병원에서 분만시 제대혈 을 기증 혹은 개인보관한 후 입원한 산부를 대상으로 아래의 선정기준에 따라 임의표출하며 구체적인 선정기준은 다음과 같다.

1) 본 연구의 목적을 이해하고 연구에 참여하기로 동의한 산부

2) 제태기간 36 주 41 주 사이의 자연분만 혹은 제왕절개 한 산부

3) 가족구성원으로 인해 제대혈 보관이 불가피했던 상태나 질환이 없는 산부

연구자와 보조 연구자가 위 선정 기준에 부합하며, 분만 후 입원하고 있는 산부를 직접 방문하여 구조화된 설문지를 배 포하고 회수 후 검토하여 불충분한 항목은 재방문하여 자료 를 수집하였으며, 자료 수집 후에는 볼펜, 물티슈와 같은 소 정의 선물을 제공하였다. 2007 년 4 월에서 7 월까지 212 명의 산 부로부터 자료를 수집하였다. G* ${ }^{*}$ power 3.10 program을 이용하 여 산출된 적정 대상자 수는 effect size $.10, \alpha$ 값 .05, 1- $\beta$ 값을 .80 으로 두었을 때 166 명이였다.

\section{3. 연구 도구}

1) 제대혈 관련 지식 도구

본 연구에서 제대혈 관련 지식 도구는 보건복지부에서 발 행된 제대혈 은행 표준업무지침(2005)과 임부를 대상으로 한 개방형 설문조사를 통하여 Lee(2006)가 개발한 제대혈 이식에 대한 지식에 관한 설문지를 바탕으로 하여 수정 보완한 설문 지로 측정한 점수를 사용하였다. 제대혈에 관한 일반적 지식 15 문항, 제대혈 보관에 관한 지식 5 문항, 제대혈 기증에 관한 지식 4문항, 총 24 문항으로 '그렇다' 1 점, ‘그렇지 않다' 0 점 으로 구성되어 있으며, 전문가 집단 17 명의 개방형 설문지와 자문을 통하여 최종 수정 보완한 후 사용하였다. 제대혈 관련 지식 측정도구의 Cronbach's alpha값은 .91이였다.

2) 제대혈 관련 태도 도구

본 연구에서 제대혈 관련 태도 도구는 본 연구자가 전문가 집단 17 명에게 개방형 설문지로 제대혈 관련 태도에 관해 물 어 질문을 구성한 뒤 다시 전문가 집단의 검정과 자문을 거 치는 델파이 방법을 통해 구성한 설문지로 측정한 점수를 사 용하였으며, 전문가 집단 구성은 제대혈 관련회사 및 현 제대
혈 은행 관련병원의 산부인과 의사와 간호사, 매니저, 교육자, 간호학 교수로 이루어졌다.

본 도구는 제대혈에 관한 일반적 태도 5 문항, 보관에 관한 태도 3 문항, 기증 관련 태도 1 문항 총 9 문항으로 구성되어 있 으며, ‘전혀 그렇지 않다' 1점에서 '매우 그렇다 '4점까지인 4 점 평정척도로 응답가능 점수의 범위는 9 36점이다. 점수가 높을수록 태도가 긍정적임을 의미하며, 본 연구에서 Cronbach's alpha값은 . 76 이였다.

\section{4. 자료 분석}

수집된 자료의 분석은 SPSS WIN 14.0 Program을 이용하여 통계처리하며, 분석방법은 다음과 같다.

1) 대상자의 제 특성에 따른 제대혈 기증과 보관 여부는 빈도 와 백분율, $\chi^{2}$-test로 분석하였다.

2) 제대혈 기증과 보관 여부에 따른 제대혈 관련 지식 정도는 빈도와 백분율, $\chi^{2}$-test, t-test로 분석하였다.

3) 제대혈 기증과 보관 여부에 따른 제대혈 관련 태도 정도는 평균, 표준편차, t-test로 분석하였다.

4) 제대혈 관련 교육 여부와 정보출처에 따른 제대혈 관련 지 식 및 태도 정도는 oneway ANOVA로 분석하였다.

5) 제대혈 활용 결정에 영향을 미친 출처에 따른 제대혈 관련 지식 및 태도 정도는 oneway ANOVA로 분석하였다.

6) 제대혈 기증과 보관의 관련 요인은 로지스틱 회귀분석으로 분석하였다.

\section{연구 결과}

\section{1. 대상자의 제 특성에 따른 제대혈 기증과 보관 여부}

제대혈을 기증 또는 보관한 산부의 일반적 특성은 < Table $1>$ 과 같다.

제대혈을 기증 또는 보관한 산부의 제 특성은 나이, 교육, 종교, 원하는 임신, 교육경험 등에서는 유의한 차이를 보이지 않았으며, 제대혈을 기증한 산부의 $64.6 \%$ 가, 보관한 산부의 $63.9 \%$ 가 제대혈 관련 교육의 경험이 없었다. 그러나 제대혈을 기증한 산부의 $35.4 \%$, 보관한 산부의 $76.2 \%$ 가 직업을 가지고 있는 등, 경제활동과 관련이 있는 직업의 유무, 직업의 종류, 수입의 정도에서 유의한 차이를 보였다.

제대혈 기증 또는 보관과 같은 결정을 하는 데 영향을 준 정보의 출처에서는 제대혈을 기증한 산부의 경우 $49.2 \%$ 가 인 터넷이나 TV로부터, $30.8 \%$ 가 의료인으로부터 정보를 얻은 반 면, 제대혈을 보관한 산부의 $32.7 \%$ 가 친구로부터, $21.8 \%$ 가 가 
$\langle$ Table 1〉 Differences in general characteristics by donating cord blood and saving cord blood.

\begin{tabular}{|c|c|c|c|c|}
\hline Characteristics & & $\begin{array}{l}\text { Donating cord blood } \\
(n=65)\end{array}$ & $\begin{array}{c}\text { Saving cord blood } \\
(n=147)\end{array}$ & $\chi^{2}$ \\
\hline \multirow{2}{*}{ Age (years) } & below 30 & $29(44.6)$ & $57(38.7)$ & \multirow{2}{*}{1.73} \\
\hline & above 30 & $36(55.8)$ & $88(61.3)$ & \\
\hline \multirow[t]{2}{*}{ Education } & High school graduate & $4(6.2)$ & $17(11.6)$ & \multirow[t]{2}{*}{1.48} \\
\hline & College graduate or more & $61(93.8)$ & $130(88.4)$ & \\
\hline \multirow[t]{2}{*}{ Employment } & Employed & $23(35.4)$ & $112(76.2)$ & \multirow[t]{2}{*}{$32.45 * *$} \\
\hline & Unemployed & $42(64.6)$ & $35(23.8)$ & \\
\hline \multirow[t]{5}{*}{ Type of Job } & Office worker & $10(15.4)$ & $67(45.6)$ & \multirow[t]{5}{*}{$39.50 * *$} \\
\hline & Teacher & $6(9.2)$ & $18(12.2)$ & \\
\hline & Commerce & $3(4.6)$ & $24(16.3)$ & \\
\hline & Health worker & $4(6.2)$ & $3(2.0)$ & \\
\hline & Unemployed & $42(64.6)$ & $35(23.8)$ & \\
\hline \multirow[t]{3}{*}{ Income } & Less than $2,000,000$ & $15(23.0)$ & $11(7.5)$ & \multirow[t]{3}{*}{$24.07 * *$} \\
\hline & $2,000,000 \sim 3,000,000$ & $28(43.1)$ & $35(23.8)$ & \\
\hline & More than $3,000,000$ & $22(33.8)$ & $101(68.7)$ & \\
\hline \multirow[t]{2}{*}{ Religion } & Religion & $45(69.5)$ & $98(66.7)$ & \multirow[t]{2}{*}{.14} \\
\hline & No Religion & $20(30.8)$ & $49(33.3)$ & \\
\hline \multirow[t]{5}{*}{ Type of religion } & Christian & $27(41.5)$ & $51(34.7)$ & \multirow[t]{5}{*}{1.78} \\
\hline & Roman Catholic & $7(10.8)$ & $13(8.8)$ & \\
\hline & Buddhism & $10(15.4)$ & $32(21.8)$ & \\
\hline & Others & $1(1.5)$ & $2(1.4)$ & \\
\hline & No Religion & $20(30.8)$ & $49(33.3)$ & \\
\hline \multirow[t]{2}{*}{ Parity } & Primipara & $36(55.4)$ & $92(62.6)$ & \multirow[t]{2}{*}{.98} \\
\hline & Multipara & $29(44.6)$ & $55(37.4)$ & \\
\hline \multirow[t]{2}{*}{ Wanted pregnancy } & Yes & $56(86.2)$ & $135(91.8)$ & \multirow[t]{2}{*}{1.63} \\
\hline & No & $9(13.8)$ & $12(8.2)$ & \\
\hline \multirow{5}{*}{$\begin{array}{l}\text { Time to be decided } \\
\text { of a use for the cord blood }\end{array}$} & Before pregnancy & $5(7.7)$ & $17(11.6)$ & \multirow[t]{5}{*}{6.51} \\
\hline & Before 3 months of the pregnancy & $1(1.5)$ & $7(4.8)$ & \\
\hline & $4 \sim 6$ months of the pregnancy & $4(6.2)$ & $21(14.3)$ & \\
\hline & Above 7 months of the pregnancy & $36(29.2)$ & $73(49.7)$ & \\
\hline & At Delivery & $19(29.2)$ & $29(19.7)$ & \\
\hline \multirow{5}{*}{$\begin{array}{l}\text { Influenced source } \\
\text { (decision of a use } \\
\text { for the cord blood) }\end{array}$} & Family & $3(4.6)$ & $32(21.8)$ & \multirow[t]{5}{*}{$95.26^{* *}$} \\
\hline & Friend & $10(15.4)$ & $48(32.7)$ & \\
\hline & Cord blood-related company & $0(0.0)$ & $42(28.6)$ & \\
\hline & Health worker & $20(30.8)$ & $21(14.3)$ & \\
\hline & Mass media(Internet \& TV) & $32(49.2)$ & $4(2.7)$ & \\
\hline \multirow{2}{*}{$\begin{array}{l}\text { Cord blood education } \\
\text { experience }\end{array}$} & Yes & $23(35.4)$ & $53(36.1)$ & \multirow[t]{2}{*}{.15} \\
\hline & No & $42(64.6)$ & $94(63.9)$ & \\
\hline Source of the cord blood & No education experience & $42(64.6)$ & $94(63.9)$ & 52.58 \\
\hline education & Cord blood-related company & $2(3.1)$ & $45(30.6)$ & \\
\hline & Health worker & $6(9.2)$ & $8(5.4)$ & \\
\hline & Mass media(Internet \& TV) & $15(23.1)$ & $0(0.0)$ & \\
\hline
\end{tabular}

${ }^{*} \mathrm{p}<.05, \quad * * \mathrm{p}<.01, \quad * * * \mathrm{p}<.001$

족으로부터 정보를 얻은 것으로 나타나 유의한 차이를 보였 다 $(\mathrm{p}<.01)$.

\section{2. 제대혈 기증과 보관여부에 따른 제대혈 관련 지식 정도}

제대혈 기증과 보관여부에 따른 제대혈 관련 지식 정도를 제대혈에 관한 일반적 지식, 제대혈 기증에 관한 지식, 제대
혈 보관에 관한 지식으로 나누어 분석한 결과는 다음과 같다 $<$ Table $2>$.

제대혈을 기증하는 산부가 개인 보관하는 산부보다 제대혈 에 대한 일반적 지식 $(\mathrm{t}=-2.06, \mathrm{p}<.05)$, 보관에 관한 지식 $(\mathrm{t}=$ -3.87, $\mathrm{p}<.01)$, 기증에 관한 지식 $(\mathrm{t}=-3.98, \mathrm{p}<.01)$ 모두 유의하게 높게 나타났다. 제대혈을 기증 또는 저장하는 산부들의 정답 률이 유의한 차이를 보이는 항목은 '개인보관하거나 기증의사 를 밝히지 않은 경우의 제대혈은 의료법에 근거하여 폐기된 


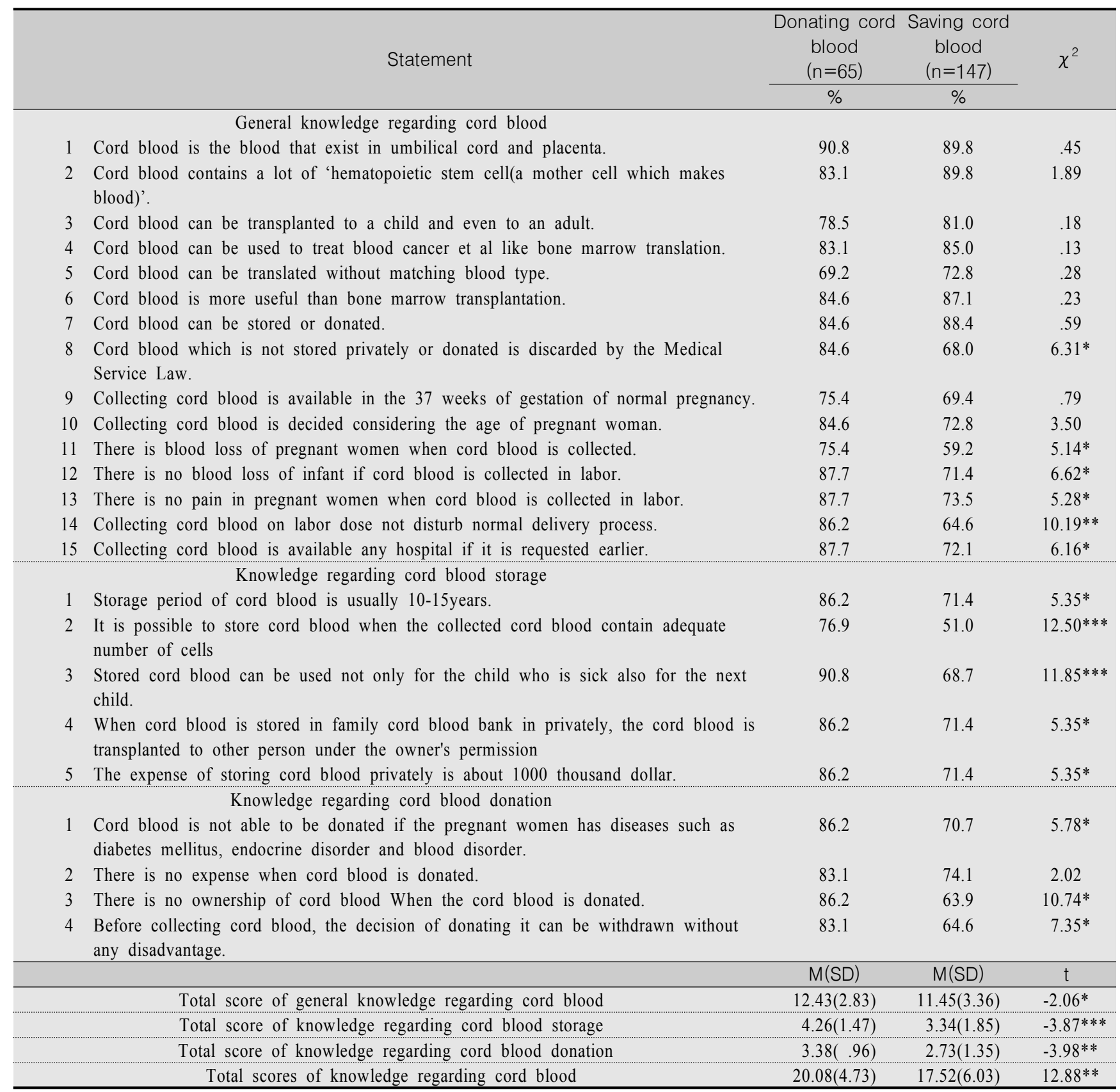

${ }^{*} \mathrm{p}<.05, \quad * * \mathrm{p}<.01, \quad * * * \mathrm{p}<.001$

다', ‘분만시 제대혈을 채취하면 신생아에게 혈액손실이 없 다, ‘분만시 제대혈을 채취하는 경우에도 정상적인 분만과정 을 방해하지는 않을 것이다', ‘제대혈을 보관해두면 이후 아이 에게 질병이 생겼을 뿐 아니라 다음 아이를 위해서도 사용할 수 있다', '제대혈을 기증하는 경우 향후 기득권(소유권)을 행 사할 수 없다' 등 14항목 이였으며, '제대혈은 태반과 탯줄에 존재하는 혈액을 말한다'라는 항목은 기증하는 산부(90.8\%)와
보관하는 산부(89.8\%) 모두에게서 가장 높은 정답률을 보였다. 제대혈을 기증하는 산부가 가장 낮은 정답률을 보인 항목 은 '제대혈은 혈액의 일치 여부와 관계없이 이식이 가능하다' 인 반면(69.2\%), 제대혈을 보관하는 산부의 경우는 '채취된 제대혈은 양과 세포수가 적절한 경우에만 보관이 가능하다' 항목에서 였다(51\%). 


\section{3. 제대혈 기증과 보관여부에 따른 제대혈 관련 태도 정도}

제대혈의 기증과 보관에 따른 대상자의 제대혈 관련 태도 정도를 일반적 태도, 보관에 관한 태도, 기증에 관한 태도로 나누어 분석한 결과, 제대혈을 기증하는 산부가 보관하는 산 부보다 제대혈에 대한 일반적 태도 $(\mathrm{t}=-6.53, \mathrm{p}<.01)$, 기증에 관 한 태도( $\mathrm{t}=-7.14, \mathrm{p}<.01)$, 보관에 관한 태도( $\mathrm{t}=-7.56, \mathrm{p}<.01)$ 모 두 유의하게 높은 것으로 나타났다<Table 3>.

제대혈을 기증한 산부의 태도 점수가 보관한 산부에 비해 서 유의하게 높은 점수를 보인 항목은 '제대혈은 난치병 치료 나 연구에 무한한 가능성을 가지고 있다고 생각한다'를 제외
한 8개 항목 에서였으며, “제대혈은 귀중한 생명을 구할 수 있을 것이다"라는 항목에서는 제대혈을 보관하는 산부 $(\mathrm{M}=$ $3.54 \mathrm{SD}=.50)$ 와 기증하는 산부 $(\mathrm{M}=3.78 \mathrm{SD}=.41)$ 모두 가장 높 은 태도점수를 나타냈다.

\section{4. 제대혈 관련 교육 여부와 정보출처에 따른 제대혈 관련 지식 및 태도}

제대혈 관련 교육 여부와 정보출처에 따른 제대혈 관련 지 식 및 태도를 분석한 결과는 <Table $4>$ 와 같다.

제대혈 관련 태도는 정보출처에 따라 유의한 차이가 있는 것으로 나타났으며 $(\mathrm{F}(3,208)=4.44, \mathrm{p}<.01)$, 제대혈 기증에 대한

〈Table 3〉 Attitude regarding cord blood

$(\mathrm{N}=212)$

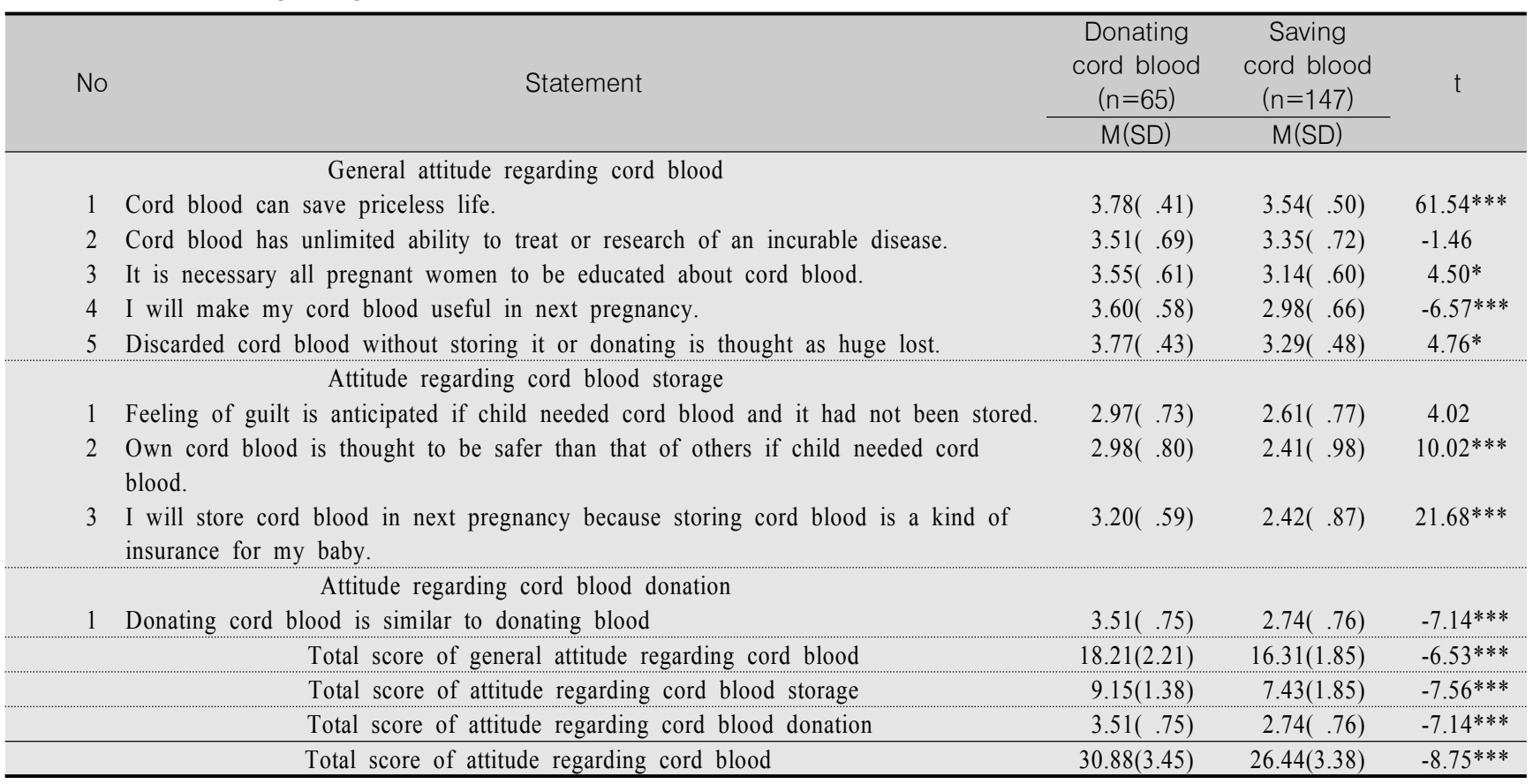

$* \mathrm{p}<.05, \quad * * \mathrm{p}<.01, \quad * * * \mathrm{p}<.001$

〈Table 4〉 Knowledge and attitude regarding cord blood according to the source of the information

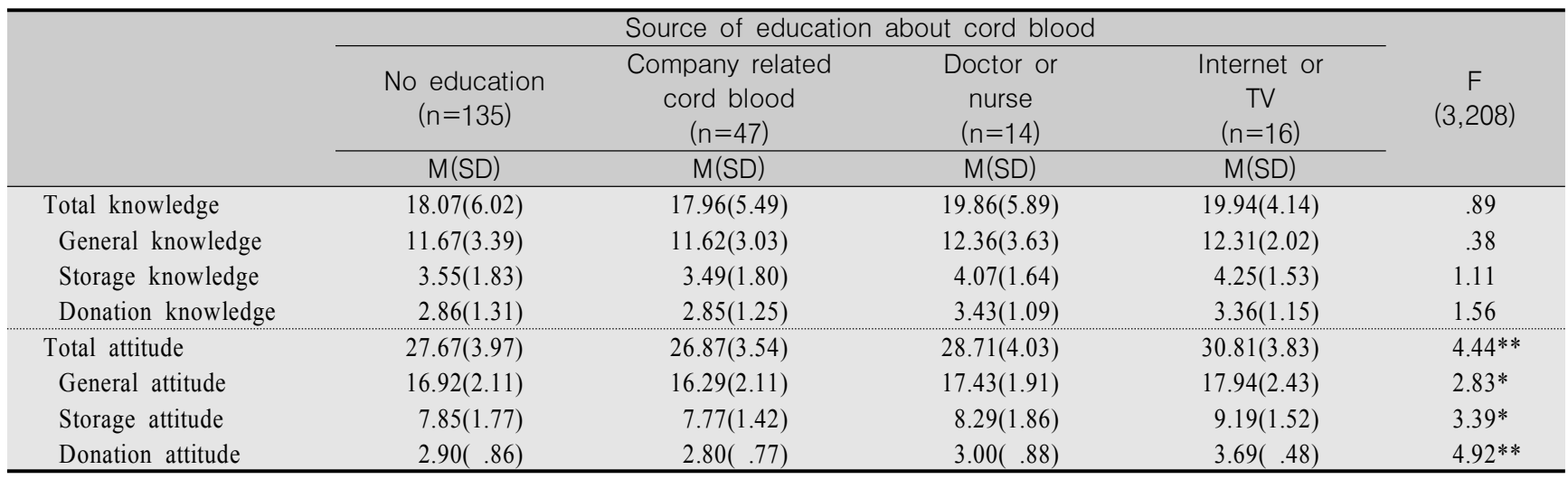


태도 $(\mathrm{F}(3,208)=4.92, \mathrm{p}<.01)$ 와 제대혈 보관에 대한 태도 $(\mathrm{F}(3,208)=3.39, \mathrm{p}<.05)$ 로 나누어 분석한 결과 또한 정보출처에 따라 유의한 차이를 나타내었다.

Sheffe test를 통한 사후조사 결과 교육을 받은 적이 없는 산부 $(\mathrm{M}=7.85, \mathrm{SD}=1.77)$ 와 인터넷이나 $\mathrm{TV}$ 를 통해서 정보를 얻 은 산부 $(\mathrm{M}=9.19 \mathrm{SD}=1.52)$ 의 제대혈 보관에 관한 태도가 유의 한 차이를 보였다. 또한 제대혈 관련 회사로부터 정보를 제공 받은 산부 $(\mathrm{M}=7.77, \mathrm{SD}=1.42)$ 와 인터넷이나 $\mathrm{TV}$ 로부터 정보를 제공받은 산부 $(\mathrm{M}=9.19 \mathrm{SD}=1.52)$ 의 제대혈 보관에 관한 태도 또한 유의한 차이가 있었다. 제대혈 기증에 관한 태도에서는 교육을 받은 적 없는 산부 $(\mathrm{M}=2.90, \mathrm{SD}=.86)$ 와 인터넷이나 $\mathrm{TV}$ 를 통해서 정보를 제공받은 산부 $(\mathrm{M}=3.69 \mathrm{SD}=.48)$ 가, 제대혈 관련 회사로부터 정보를 제공받은 산부 $(\mathrm{M}=2.80, \mathrm{SD}=.77)$ 와 인터넷이나 $\mathrm{TV}$ 를 통해 정보를 제공받은 산부 $(\mathrm{M}=3.69 \mathrm{SD}=$ 48)가 유의한 차이를 보였다.

\section{5. 제대혈 활용의 결정에 영향을 미친 출처에 따른 제대혈 관련 지식 및 태도}

제대혈 활용 결정에 영향을 미친 출처에 따른 제대혈 관련 지식과 태도의 각 항목 점수를 분석한 결과 제대혈에 대한 일반적 태도 $(\mathrm{F}(4,207)=3.08, \mathrm{p}<.05)$ 와 기증에 대한 태도( $\mathrm{F}$ $(4,207)=3.83, \mathrm{p}<.01)$, 제대혈 보관에 관한 태도 $(\mathrm{F}(4,207)=5.71$, $\mathrm{p}<.01)$ 가 유의한 차이를 보였다<Table 5>.

Sheffe test를 통한 사후조사 결과, 제대혈에 관한 일반적 태 도 정도는 제대혈 관련 회사로부터 제대혈 활용 결정에 대한 영향을 받은 산부 $(\mathrm{M}=16.33, \mathrm{SD}=1.98)$ 와 인터넷이나 $\mathrm{TV}$ 의 영 향을 받은 산부 $(\mathrm{M}=17.89 \mathrm{SD}=2.36)$ 사이에서 유의한 차이를 보이는 것으로 나타났다. 제대혈 기증에 관한 태도는 제대혈 관련 회사 $(\mathrm{M}=2.64, \mathrm{SD}=.85)$ 와 인터넷과 $\mathrm{TV}(\mathrm{M}=3.36, \mathrm{SD}=.90)$
를 통해 제대혈 활용의 결정에 영향을 받은 산부 사이에서 유의한 차이가 있었다. 제대혈 저장에 대한 태도를 보면, 친 구나 동료로부터 영향을 받은 산부 $(\mathrm{M}=7.76, \mathrm{SD}=1.67)$ 와 인터 넷 또는 $\mathrm{TV}$ 로부터 영향을 받은 산부 $(\mathrm{M}=9.08 \mathrm{SD}=1.54)$ 에서 유의한 차이를 보이는 것으로 나타났으며, 또한 제대혈 관련 회사로부터 영향을 받은 산부( $\mathrm{M}=7.48, \mathrm{SD}=1.81)$ 와 인터넷 또 는 $\mathrm{TV}$ 를 통해서 영향을 받은 산부( $\mathrm{M}=9.08 \mathrm{SD}=1.54)$, 그리고 가족의 영향을 받은 산부 $(\mathrm{M}=7.63, \mathrm{SD}=1.54)$ 와 인터넷 또는 $\mathrm{TV}$ 를 통해서 영향을 받은 산부 $(\mathrm{M}=9.08 \mathrm{SD}=1.54)$ 사이에서 유의한 차이를 나타내었다.

\section{6. 제대혈 기증과 보관 관련요인}

제대혈 기증에 영향을 미치는 관련 요인에 대한 로지스틱 분석 결과, 제대혈의 기증은 직업의 유무, 수입 정도, 제대혈 관련 지식, 제대혈 관련 태도 정도에 따라 영향 받는 것으로 나타났다<Table 6>.

직업이 없는 산부가 있는 산부에 비해, 수입이 300 만 원 이

〈Table 6〉 Logistic Regression Predicting Donating Cord blood

$(\mathrm{N}=212)$

\begin{tabular}{lrcc}
\hline \multicolumn{1}{c}{ Predictor } & $\beta$ & Wald $\chi^{2}$ & Odd ratio \\
\hline Age $>30$ & .19 & .21 & 1.21 \\
Employment & -1.39 & 9.65 & $.25 * *$ \\
Income $>3,000,000$ won & -1.14 & 6.24 & $.32 *$ \\
Religion & .10 & .05 & 1.10 \\
Parity & .04 & .01 & 1.04 \\
Wanted pregnancy & .04 & .0024 & 1.04 \\
Cord blood related education & .01 & .0009 & 1.01 \\
Total knowledge about cord blood & .08 & 4.46 & $1.08 *$ \\
Total attitude about cord blood & .37 & 37.23 & $1.45 * * *$ \\
Constant & -11.93 & 35.54 & \\
* $\mathrm{p}<.05, * * \mathrm{p}<.01, * * * \mathrm{p}<.001$ & & & \\
\end{tabular}

$\langle$ Table 5〉 Knowledge and attitude regarding cord blood according to the source influencing decision to use cord blood

$(\mathrm{N}=212)$

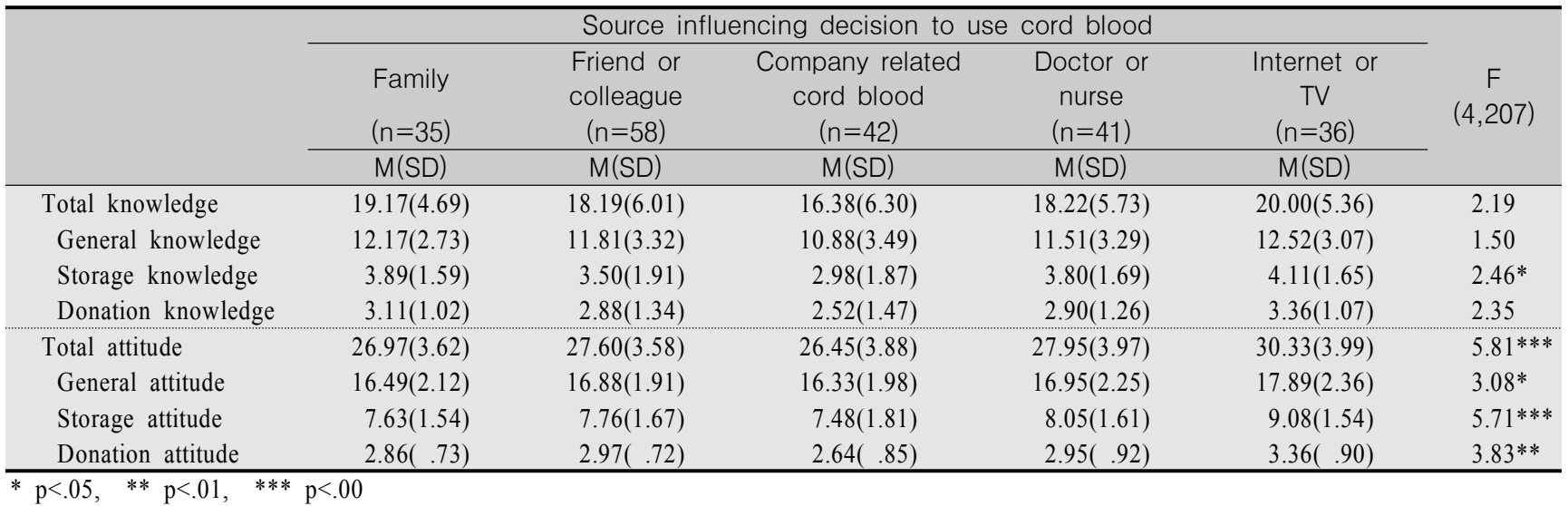


하인 경우의 산부가 수입 300 만 원 이상인 산부의 경우보다 더 많이 기증하는 경향이 있는 것으로 나타났다. 또한, 제대혈 관련 지식이 높은 산부가 그렇지 못한 산부에 비해 1.08 배, 제 대혈 관련 태도가 좋은 산부가 그렇지 못한 산부에 비해 1.45 배 더 많이 기증을 하는 경향이 있는 것으로 나타났다.

\section{논 의}

본 연구에서 제대혈 기증 및 보관 여부에 따른 제대혈 관 련 지식 정도는 제대혈을 기증한 산부의 경우 총 24 점 중 12.43 점으로 중간보다 다소 높은 점수를, 개인 보관한 산부의 경우 11.45 점으로 중간 이하의 점수를 보였다. 제대혈 관련 지식을 일반적 지식과 기증에 관한 지식 및 보관에 관한 지 식으로 나누어 분석한 결과 또한 제대혈을 기증한 산부가 개 인 보관한 산부보다 세 항목 모두에서 지식 점수가 유의하게 높은 것으로 나타나 Fox 등(2007)의 연구결과와 일치하였다.

'제대혈은 태반과 탯줄에 존재하는 혈액을 말한다'라는 항목 은 기증 또는 보관한 산부 모두에게서 가장 높은 정답률을 나타내 Lee(2006)의 연구에서 $85 \%$ 의 정답률을 보인 것과 동 일한 결과를 보여 제대혈의 정의에 대해서는 두 군 모두 잘 알고 있는 것을 알 수 있었다. 그러나 '공여 제대혈 은행에 제대혈을 기증한 경우 산모가 필요시 언제든 이용가능하다'는 항목에서 임부의 $18 \%$ 가 정답을 표기한 Lee(2006)의 연구결과 와는 달리 본 연구에서는 '제대혈을 기증하는 경우 향후 기득 권(소유권)을 행사할 수 없다'는 항목의 정답률이 제대혈 보 관 산부 $63.9 \%$, 기증 산부 $86.2 \%$ 로 높게 나타났다. 이는 2006년 3월 이후 국내 제대혈 은행 수가 16개를 넘어서면서 제대혈 관련 홍보와 교육이 더 활발히 이루어졌고, 그 결과 제대혈에 관한 지식 정도가 향상되었기 때문인 것으로 생각 되어지며, 이 같은 결과는 차병원 아이코드(2006)의 설문조사 결과 임부의 $90 \%$ 가 향후 제대혈 보관의사가 있으며, $71 \%$ 가 미래 난치병 치료의 대안이라고 답한 결과에서도 잘 나타나 는 것을 볼 수 있다.

또한 '개인보관하거나 기증의사를 밝히지 않은 경우의 제대 혈은 의료법에 근거하여 폐기된다', '분만시 제대혈을 채취하 면 신생아에게 혈액손실이 없다', '분만시 제대혈을 채취하는 경우에도 정상적인 분만과정을 방해하지는 않을 것이다'의 항 목에서 제대혈을 기증한 산부가 보관한 산부에 비해 높은 정 답률을 나타내, 제대혈을 기증한 산부가 제대혈의 사후처리와 채취과정에 대해 더 정확히 알고 있음을 알 수 있었다.

그러나 제대혈을 기증한 산부가 가장 낮은 정답률을 보인 항목이 “제대혈은 혈액의 일치 여부와 관계없이 이식이 가능 하다"인 것으로 보아, 제대혈에 대한 교육과 홍보의 노력에도 불구하고 아직까지는 제대혈에 대한 부분적인 정보를 이해하
고 있는 데에 그치고 있는 것으로 생각되며, 이는 체계적인 교 육을 통한 정보 습득의 필요성이 제기되는 부분이라 하겠다.

본 연구에서 제대혈 기증 및 보관 여부에 따른 제대혈 관 련 태도 정도는 총 36 점 중 제대혈 기증한 산부가 30.88점으 로 제대혈을 보관한 경우의 산부가 26.44점에 비해 높았으며, 제대혈을 기증한 산부가 보관한 산부보다 제대혈 관련 태도 의 세부항목인 제대혈에 대한 일반적 태도, 보관에 관한 태 도, 기증에 관한 태도 모두 유의하게 높은 것으로 나타났다.

특히 '나는 다음 임신 시에도 나의 제대혈이 활용될 수 있 도록 할 것이다', ‘제대혈이 개인보관이나 기증의 의사 없이 버려지는 것은 큰 손실이라 생각한다', '제대혈을 기증하는 것 은 헌혈과 비슷한 의미를 가진다고 생각한다'라는 항목에서 제대혈을 보관한 산부에 비해 제대혈을 기증한 산부의 태도 점수가 높은 것으로 나타났다.

Danzer 등(2003)의 연구에서 제대혈을 기증한 산부의 $96.1 \%$ 가 다시 제대혈을 기증하고 싶다고 답하였고, Lee(2006)의 연 구에서도 이전에 제대혈 기증 경험이 있는 임부의 $100 \%$ 가 출 산 시에 다시 제대혈을 기증하겠다고 답하면서 기증계획을 세우고 있는 임부의 $52 \%$ 가 '모두 기증하면 많은 사람에게 기 회가 주어짐'이라고 응답하는 등 제대혈 기증에 대해 긍정적 인 태도를 보였다.

Fernandez, Gordon, Van den Hof, Taweel와 Baylis(2003)의 연구에서 헌혈 경험이 제대혈 활용을 결정하는데 유용한 변 수로 확인되었는데, 본 연구에서도 '제대혈을 기증하는 것은 헌혈과 비슷한 의미를 가진다고 생각한다'에서 제대혈을 기증 한 산부의 점수가 3.51 점으로 제대혈을 보관한 산부의 2.74 점 에 비해 높았다. 이는 제대혈 관련 태도가 헌혈, 장기기증 결 정의 경우에서처럼 대상자 개개인의 가치관 등에 영향을 받 기 때문인 것으로 생각된다.

반면 Danzer 등(2003)의 연구에서는 제대혈을 다시 기증하 지 않겠다고 결정한 대상자의 태도가 부정적인 것으로 나타 나 유의한 상관관계를 보였는데, 이는 제대혈 기증 절차가 구 체적이고 체계화되어 있음에도 불구하고, 제대혈 은행에서 유 전적 검사 등으로 부적절하게 사용될 것을 우려해서 인 것으 로 드러났다.

제대혈 관련 교육여부와 정보출처에 따른 제대혈 관련 지 식 및 태도 정도를 분석한 결과 정보출처에 따라 제대혈 기 증에 관한 태도와 보관에 관한 태도가 유의한 차이를 보였는 데, 인터넷이나 $\mathrm{TV}$ 로부터 정보를 제공받은 산부가 제대혈 관 련 회사로부터 정보를 제공받은 산부에 비해, 교육을 받지 못 한 경우보다 인터넷 등을 통하여 정보를 얻은 경우에서 유의 하게 높은 점수를 보였다. 이는 제대혈 활용을 결정하는데 있 어 정보가 중요한 요인으로 작용함을 의미하는 결과라 할 수 있겠다. 또한 제대혈 활용 결정에 영향을 미친 출처에 따른 
제대혈 관련 지식과 태도 정도를 분석한 결과에서도 동일한 결과를 보였는데, 제대혈에 대한 일반적 태도와 기증과 보관 에 관한 태도는 제대혈 관련 회사보다는 대중매체를 통해 더 많은 영향을 받는 것을 알 수 있었고, 대중매체를 통하여 제 대혈의 유용성과 공여 제대혈 은행의 활성화의 필요성 등이 알려진 것이 기증을 선택하는 데에 영향을 미친 것이라 생각 할 수 있겠다.

더불어 제대혈의 유용성과 보관, 채취과정에 대한 올바른 이해를 위해서는 산전관리 동안 산전교육의 일환으로 체계적 교육이 이루어지는 것이 더 바람직하다 볼 수 있다. 이는 Kharaboyan, Knoppers, Avard와 Nisker(2007)가 제대혈 기증 산부에게 제대혈을 기증하는 데에 동의하기 전에 충분한 이 해를 위해 완벽하고 정확한 정보가 필요하며, 제대혈을 보관 하는 경우 역시 제대혈 보관에 관한 동의가 분만 전에 이루 어지는 것을 고려한다면, 산전교육 시에 제대혈에 관한 윤리 적, 법적, 전문적 이유들에 관한 교육을 받는 것이 바람직하 다고 제언한 바 있다. 또한 Fox 등(2007)은 산부인과 의사는 제대혈 은행에 관한 모든 정보를 임부에게 제공해야 하며, 제 대혈 은행에 관한 현명한 결정을 할 기회를 모든 임부들에게 제공하는 것을 목표로 그들의 의사결정을 도와야 한다고 주 장했다.

제대혈 기증에 영향을 미치는 요인은 직업의 유무, 수입 정 도, 제대혈 보관에 대한 태도, 제대혈 기증에 대한 태도에 따 라 영향 받는 것으로 나타났다.

직업이 없고 수입이 적은 산부일수록 기증하는 경향이 있 는 것으로 나타난 것은 제대혈 개인 보관비용이 100 만원을 넘어서서 출산-육아와 함께 비용부담으로 여기지기 때문인 것 으로 생각되어지며, 이는 Lee(2006)의 연구에서 직업이 없고 수입이 낮은 경우의 임부가 제대혈을 개인보관 또는 기증하 기 보다는 폐기할 의사를 밝힌 것에서처럼 비용부담이 제대 혈 기증의 방해요인의 하나로 작용하고 있음을 알 수 있다. 반면, Fernandez 등(2003)의 연구에서는 고소득이 제대혈의 기 증이나 보관을 결정하는 중요한 요소는 아니라고 보고한 바 있다.

제대혈 기증과 보관에 대해 좋은 태도를 보이는 산부일수 록 기증하는 경향이 있는 것으로 나타난 데에는 제대혈 기증 역시 헌혈과 같이 타인을 위한 봉사와 희생이 바탕이 될 때 더 많이 선택되어 질 수 있기 때문인 것으로 여겨진다. 그러 나 제대혈 관련 지식 정도는 제대혈 기증과 보관 결정 여부 에 중요한 영향 변수로 작용하지 않았는데, 263 명의 임부를 대상으로 실시한 Fernandez 등(2003)의 연구에서도 제대혈 보 관과 기증을 선택함에 있어 제대혈에 관한 지식 정도는 유의 하지 않았다고 보고하였다.

현재 공공 목적으로 공여 제대혈 은행을 운영하고 있는 몇
제대혈 보관 회사와 일부 대학병원에서 1 만 4000 명의 탯줄혈 액을 보관하고 있으며, 보관 혈액 수가 8 만개가 되면 백혈병 환자의 $90 \%$ 가 이식수술을 받을 수 있고 6 만개이면 70 80\% 의 환자가 혜택을 볼 수 있다고 한다(Kim, 2008). 그러나 2005년 국내 공여 제대혈이 약 7만 단위 이상으로 파악되었 다 하더라도, 우리나라의 공여 제대혈 보관사업이 외국의 경 우와는 달리 $95 \%$ 이상에서 수익을 목적으로 하는 상업용 제 대혈 은행을 중심으로 운행되는 것이 문제점으로 지적된 바 있다(Lee, 2006). Kim(2008)은 우리나라에서 약 30 만 명이 가 족 제대혈이 등록되어 있으나, 그 중 실질적으로 제대혈을 이 식받은 경우는 3 명에 불과하며, 그에 반해 공여 제대혈은 약 3 만 명이 등록되어 있는데 이미 300 개의 제대혈이 이용되어 가족 제대혈에 비해서 천 배 정도 더 효율적인 시스템이라고 보고하면서, 다른 환자들을 위해서 기증된 공여 제대혈조차도 효율적으로 사용되지 못하고 있음을 안타까워하였고 국가 차 원에서 체계적으로 제대혈을 관리하고 제대혈 이식 비용에 대한 지원이 필요함을 강조하였다.

이제 우리나라도 제대혈 기증이 공공의료적인 의미를 가져 야 하며 품질관리 또한 국가차원의 적극적 관리가 이루어져 야 할 것이며(Lee, 2008), 더불어 모든 기증 제대혈 정보의 효 율적 관리 정보시스템의 필요와 함께 이러한 제도적 뒷받침 마련 후에 효율적인 제대혈 홍보가 이루어지는 것이 바람직 할 것이다(Yoon, 2008).

현행법에선 HLA가 일치하는 제대혈 이식 수술에 한해서만 보험을 인정하고 있어 5 천만 1 억 원에 이르는 치료비를 감당 해야 하며, 제대혈 이식에도 희박하긴 하지만 감수해야 할 위 험이 존재하고 있는 점, 또한 하나의 탯줄에서 채취한 조혈모 세포의 절대량이 부족하기 때문에 그 대상이 주로 $40 ~ 50 \mathrm{~kg}$ 이 하인 소아 환자들에 제한되는 한계를 가지고 있는 점, 현행법 상 태반과 탯줄은 병원에서 나오는 적출물로 분리해 소각하 도록 되어 있는 점 등은 제대혈의 여러 가지 유용성에도 불 구하고 여전히 남아 있는 몇 가지 문제점 들이라 할 수 있다 (MBC, 2008). 비록 이러한 문제점들이 여전히 산제하고 있다 하더라도 제대혈에 관한 활발한 연구를 통해 더 많은 의료부 분에서 유용하게 사용되어질 수 있음을 고려한다면, 제대혈에 관한 지식과 태도의 긍정적 향상을 통해 제대혈 활용을 높일 수 있는 사회적 환경을 조성하여 국내 제대혈에 관한 효율성 을 높여야 할 것이며, 나아가 국가 정책의 일환으로 확산되어 야 할 필요성을 간과해서는 안 될 것이다.

\section{결론 및 제언}

본 연구는 제대혈 관련 지식 및 태도를 파악하고 제대혈 기증과 보관에 관한 관련요인을 규명함으로 제대혈에 관한 
올바른 인식을 통한 제대혈의 유용성을 높일 수 있는 효율적 인 간호 관리와 국가적 차원의 운영시스템 구축의 필요성을 제기하기 위한 기초자료를 얻고자 서울, 경기 소재 2곳의 산 부인과 전문병원에서 분만한 산부 212 명을 대상으로 시행한 서술적 조사연구이다. 연구도구는 일반적 특성 및 산과적 특 성, 제대혈 관련 지식과 태도 측정 도구를 이용였으며 결과는 다음과 같다.

제대혈을 기증 또는 보관한 산부의 일반적 특성에서 기증 한 산부, 보관한 산부 모두 대부분 제대혈 관련 교육 경험이 없었으며, 직업의 유무, 직업의 종류, 수입의 정도에서 그리고 제대혈을 기증 또는 보관의 결정을 하는데 영향을 준 정보 출처에서 유의한 차이를 보였다. 제대혈 관련 지식 태도 정도 는 제대혈을 기증하는 산부가 개인 보관하는 산부에 비해 제 대혈에 대한 일반적 지식과 태도, 보관에 관한 지식과 태도, 그리고 기증에 관한 지식과 태도에 관하여 모두 유의하게 높 게 나타났으며, 제대혈 관련 태도는 정보 출처에 따라서 유의 한 차이가 있었다. 제대혈 활용 결정에 영향을 미친 출처에 따른 제대혈 관련 지식과 태도는 제대혈에 관한 일반적 태도 와 제대혈 저장에 관한 태도, 기증에 대한 태도가 유의한 차 이를 보였으며, 제대혈 기증에 영향을 미치는 관련 요인을 살 펴 보았을 때, 제대혈의 기증은 직업의 유무, 수입 정도, 제대 혈 관련 지식, 그리고 제대혈 관련 태도 정도에 따라 영향 받 는 것으로 나타났다.

이상의 결과를 종합하여 볼 때, 제대혈 기증과 보관에는 제 대혈 관련 태도 정도가 영향을 주는 요인임을 알 수 있었으 며, 제대혈 관련 지식 및 태도 정도는 제대혈 보관 군에 비해 제대혈 기증군에서 더 높음을 알 수 있었다. 이러한 결과는 제대혈 보관을 선택함에 있어 체계적인 교육이 이루어질 필 요성을 제기하는 것이며, 제대혈 기증 또한 대상자들이 정확 하게 알고 판단할 수 있도록 도우는 것이 필요할 것이라 생 각된다. 또한 직업과 수입정도가 관련요인으로 밝혀져 제대혈 개인보관에 대한 비용부담이 제대혈 활용 선택에 있어 중요 한 변수로 작용함을 확인할 수 있었다.

본 연구의 결과를 토대로 다음과 같이 제언하고자 한다.

- 제대혈을 폐기한 경우의 산부들을 포함한 추후연구가 필요 하다.

- 병원 내에서의 제대혈 회사 홍보와 역할, 의료인들의 홍보 와 관리방법 등을 고려한 반복연구가 필요하다.

- 임부들의 제대혈 활용 계획 선택 경로를 규명하는 연구가 필요하다.

- 임부들이 제대혈 활용 계획을 선택함에 있어 체계적인 교육 의 필요에 따른 중재연구가 필요하다.
- 국가적 차원의 제대혈 활용 방안 모색과 함께 의료인의 역 할이 강조되어짐에 따라 의료인의 제대혈 관련 지식과 태 도를 측정하는 연구가 필요하다.

\section{References}

Arcese, W., Picardi, A., Cerretti, R., Cudillo, L., De Angelis, G., Franceschini, L., De Felice, L., \& Postorino, M. (2006). The therapeutic use of cord blood. Cell Preserv Technol, 4(3), 161-168.

Cho, K. E. (2007 May 14). Nine out of ten pregnant women said "I want to store cord blood". Seoul Medical Today.

Danzer, E., Holzgreve, W., Troeger, C., Kostka, U., Steimann, S., Bitzer, J., Gratwohl, A., Ticheli, A., Seelmann, K., \& Surbeck, D. V. (2003). Attitudes of Swiss mothers toward unrelated umbilical cord blood banking 6 months after donation. Transfusion, 43(5), 604-608.

Fernandez, C. V., Gordon, K., Van den Hof, M., Taweel, S., \& Baylis, F. (2003). Knowledge and attitudes of pregnant women with regard to collection, testing and banking of cord blood stem cells. CMAJ, 18;168(6), 695-698.

Fox, S. F., Stevens, C., Ciubotariu, R., Rubinsten, P., McCullough, L. B., \& Chervenak, F. A. (2007). Umbilical cord blood collection: do patients really understand? J Perinat Med 35, 314-321.

Gluckman, E. (2000). Ethical and legal aspects of placental/cord blood banking and transplant. Hematol J, 1(1). 67-69.

Han, H. (2001). Home and abroad status of cord blood bank and proper direction of home cord blood bank. The second symposium of cord blood cell transplantation.(pp 5-6). Seoul.

I-cord (2006). Survey of storage status and knowledge regarding umbilical cord blood. Cha Heatlh system.

Kharaboyan, L., Knoppers, B. M., Avard, D., \& Nisker, J. (2007). Understanding umbilical cord blood banking what women need to know before deciding, Women's Health Issues, 17, 277-280.

Kim, T. G. (2008). Usage plans and public medical meaning of cord blood donation. Symposium: How can we share the lives?(pp 61-67). Seoul: PBC.

Lee, E. Y. (2006). Pregnant women's knowledge regarding cord blood transplantation and awareness regarding usages of cord blood, Unpublished master's thesis, Busan University.

Lee, Y. H. (2006). Establishment of development and managing system for public cord blood bank. Ministry of Health and Welfare. Korea.

Lee, Y. H. (2008). Usage plans and public medical meaning of cord blood donation. Symposium:How can we share the lives?(pp 68-72). Seoul: PBC.

MBC (2008). Crisis of umbilical cord blood. Sisa Magazine 2580, February 3.

Surbek, D. V., Islebe, A., Schonfeld, B., Tichelli, A., Gratwohl, A., \& Holzgreve, W. (1998). Umbilical cord blood transplantation: acceptance of umbilical cord blood donation by pregnant patients, Schweiz Med Wochenschr, 2;128(18), 
689-695.

The standard recommendation on the operation of umbilical cord blood bank. (2005). Ministry of Health and Welfare. Korea.
Yoon, J. H. (2008). Public cord blood bank. Symposium:How can we share the lives?(pp 73-76). Seoul: PBC.

YTN (2007). Story of cord blood. Na Do Sun the story of life science, January 22. 